\title{
ФИЛОСОФИЯ
}

\author{
UDC 172.2
}

\section{Probable opinions and solid outcomes: On the methodology of ethical expertise in the cultural sphere}

\author{
A.I. Brodsky \\ St. Petersburg State University, \\ 7-9, Universitetskaya nab., St. Petersburg, 199034, Russian Federation
}

For citation: Brodsky A. I. Probable opinions and solid outcomes: On the methodology of ethical expertise in the cultural sphere. Vestnik of Saint Petersburg University. Philosophy and Conflict Studies, 2018, vol. 34, issue 3, pp. 324-332. https://doi.org/10.21638/11701/spbu17.2018.301

When we attempt to apply the principles of ethical expertise - which originated, after all, in the field of biomedicine - to the sphere of culture, we face the fundamental problem of any expertise: the lack of a methodology that will enable at least the partial elimination of the influence of "subjective factors", ranging from experts' ideological and religious preferences to their personal moral qualities and emotional responses. This paper aims to develop such a methodology. To resolve this problem, the author proposes to revisit the forgotten art of casuistry, which was flourishing at the end of the $16^{\text {th }}$ and beginning of the $17^{\text {th }}$ centuries. At that time, the golden rule of casuistry was to regard various ethical principles and norms as more or less plausible opinions (opinion probabilis). One could choose one of these opinions only after discussion and evaluation of each opinion and its outcomes in each specific case. Today, the use of casuistry in ethical expertise means that experts can proceed not from their own convictions and principles, but from an assessment of a specific situation, and a comparison between possible consequences resulting from the application of certain moral requirements to that situation. Only those conclusions which satisfy all the experts can be termed "justified". However, such a consensus will be impossible if the experts base their conclusions not on an analysis of the consequences of a specific decision, but on their own favoured religious or ideological doctrines. Theoretically speaking, the author believes that casuistry as a method of ethical expertise implies not only an assessment of a particular case from the point of view of the general principles of morality but also the evaluation of these principles in light of their applicability to particular cases.

Keywords: ethics, expertise, culture, casuistry, opinions.

${ }^{*}$ This article was prepared for the Russian Foundation for Basic Research (RFBR), project Nr. 18-01100673 «Methodology of ethical expertise in the field of culture».

(c) Санкт-Петербургский государственный университет, 2018 


\section{Introduction}

Ethical expertise originated in the field of biomedicine, and now is actively employed in other spheres of public life, including business, education, mass-media, etc. In any application, its goal is to assess how an event or action can affect the physical and psychological state of a person, their values, dignity, freedom, etc. However, the more widespread the use of ethical expertise becomes, the more obvious are the problems and contradictions associated with it, and first and foremost, we are handicapped by the absence of any sound methodology. For this reason, the results of ethical expertise depend completely upon society's "moral stereotypes", which are usually contradictory, bigoted, and abstract (that is, not applicable to specific cases), as well as upon experts' "personal qualities" and ideological predispositions.

But it is probably in the sphere of culture that ethical expertise has been most dramatically compromised. On the one hand, it is obvious that today some kind of ethical evaluation of cultural phenomena is necessary: modern society constantly faces manifestations of extremism, xenophobia, religious fanaticism, etc., which are often disseminated through various cultural products (fiction, historical narratives, biased textbooks, provocative films and theatrical productions) as well as the resurgence of ethically unacceptable traditions. But on the other hand, so-called "pseudo-ethical expertise" is extremely common here: under the guise of ethical expertise, culture is subjected to ideological pressure, the authorities demonstrate religious or ethnic intolerance and exercise political decisions. We can even name certain cases when so-called "ethical expertise" became the means to justify the seizure of cultural property (theaters, libraries, museums) or to eliminate rivals. Of course, the majority of these incidents should be subject to legal assessment, but they also reveal the intrinsic problem of any ethical expertise: the lack of a methodology enabling the elimination of the so-called "subjective factor".

Undoubtedly, any methodology seeks to eliminate the "subjective factor" and bring a researcher as close to an "objective truth" as possible. But can we achieve this in the sphere of morality, where judgments (from the position of logic and semantics) do not correspond to any "objective reality" at all, and consequently cannot be either true or false? In this paper, we do not need to list all the arguments against ethical objectivism formulated throughout the history of philosophy, from the Sophists to the postmodernists. Suffice it to emphasize that the desire to find some solid foundation for our moral decisions and to exclude alternative forms of behavior is not only unachievable but also conflicts with the very essence of morality. As Karl Popper rightly noted, "if it could be achieved, it would destroy all personal responsibility and consequently all ethics" [1, p. 207, n. 18]. Morality always implies decision or choice, and when we speak about decision or choice, there will not and can not be any one truth. It is, for example, impossible to decide or to choose that two times two equals four.

However, Aristotle already understood that, in addition to the theoretical, there is a practical reason, and the conclusions of practical reason are not arbitrary, though they do not represent the results of the cognition of "objective reality". He emphasized that our ethical reasoning cannot, of course, be as accurate as our reasoning about objective reality. But "Now fine and just actions, which political science investigates, admit of much variety and fluctuation of opinion, so that they may be thought to exist only by convention, and not by nature" $[2,1094 \mathrm{~b} 14-17]$. In the search for an adequate methodology for ethical expertise, 
it is, in my opinion, worthwhile to remember two sciences which date back to Aristotelianism and are forgotten in the modern era. Of course, they are far from being as precise as the natural sciences, logic, and mathematics, but they still enable us to eliminate voluntarism in value judgments. These two sciences are ethical (legal) hermeneutics and casuistry.

\section{Hermeneutics}

Since the age of Romanticism, hermeneutics has been primarily viewed as the art of understanding. Here we can speak about an understanding of the original meaning of a text, an author's idea, which belongs to another space or time, and so on. Whatever the case, the task is to comprehend something alien to our own consciousness, to include some unfamiliar material in our own system of ideas and concepts. However, in times preceding the era of Romanticism, hermeneutics had another goal. For example, in the Middle Ages hermeneutics aimed not so much to understand a text, as to use it. Whether it was about the Holy Scripture or a law book, a hermeneut strove not to understand an author's idea or to grasp the "spirit of the past", but rather to link this text with a current situation to which it could be applied. In the second half of the $19^{\text {th }}$ century, Hans-Georg Gadamer came to the controversial conclusion that understanding itself is impossible without an application. "In the course of our reflections," - the philosopher wrote, - "we have come to see that understanding always involves something like applying the text to be understood to the interpreter's present situation" [3, p.306-307]. Of course, these conclusions by an authoritative philosopher contributed to a certain revival of interest in the medieval art of hermeneutics. However, even Gadamer saw the application of hermeneutics as a tool for understanding and not as something significant by itself. In my opinion, the "hermeneutics of application" is an independent activity as useful today as it was in the Middle Ages, but requiring some methodological modernization.

It was Judaism that in the first centuries $\mathrm{AD}$ primarily postulated the methodological problems connected with the application of the biblical commandments to the endless variety of specific cases. In early Christianity, these problems lost their significance as the New Testament gave "spirit" priority over "letter", i.e. preached that faith and love allow a person to act in accordance with the Law without any further reasoning. Therefore, the foundations of all subsequent ethical and legal hermeneutics were established by those Jewish preachers whose work led to the creation of the Babylonian and Jerusalem Talmud.

The methodology of ethical and theological hermeneutics (or Middot) was shaped by the seven rules of Hillel ( $1^{\text {st }}$ century AD). These rules can be conveniently translated as follows: 1) analogy; 2) conclusion from simple to complex; 3) conclusion based on the identity of the expressions; 4) conclusion from two contradicting texts (when we should find the third text removing the contradiction); 5) conclusion made by finding the main (common) premise; 6) reasoning from general to particular; 7) conclusion from the context. With the help of these rules, laws, and stories of the Torah could be applied to actual cases and circumstances.

Researchers have repeatedly noted that the rules of Hillel do not go beyond Aristotelian syllogistics. In fact, as an expert on the Talmud Yehuda Leib Katsnelson emphasized at the beginning of the last century, the difference between Hillel's and Aristotelian syllogistics lies in the fact that the former was invulnerable to John Stuart Mill's attacks. It is well known that Mill reproached Aristotelian syllogism for an internal contradiction. For 
example, the reasoning: "All people are mortal / Kai is a person / Therefore, Kai is mortal", - contains an obvious contradiction. If, while building a syllogism, I set a question about Kai's mortality, I already have some doubts and, therefore, have no right to say that all people are mortal. According to Katzenelson, Hillel does not have such a contradiction, due to the fact that Aristotle speaks about the phenomena of life (which by their very nature are unfinished, i.e., derived from the so-called "incomplete induction"), while Hillel discusses the law established by God, and thus the major premise of his syllogisms is $a$ priori absolute [4]. As we will see, this distinction between biblical hermeneutics and Aristotelian syllogistics will become a turning point in the formation of European casuistry of the $16^{\text {th }}$ and $17^{\text {th }}$ centuries.

As for the Middot, its further development resulted in the increase of the number of methods. Thus, in the $2^{\text {nd }}$ century AD, Rabbi Ishmael ben Elisha turned the seven rules of Hillel into thirteen; Rabbi Eliezer ben Rabbi Yossi Haglili established thirty two rules; finally, in the $19^{\text {th }}$ century, Malbim (Meir Leibush ben Yehiel Michel Wisser) compiled a list of six hundred and thirteen rules for commenting on a text. The only invariable conviction was that three principles are correct: 1 ) the principle of the absolute truth of initial premises (the Law); 2) the principle of the impossibility of contradictions (God does not contradict Himself); and 3) the "default" principle allowing for the usage of Aristotelian logic of genusspecies relations. In my opinion, this very increase in the number of rules indicates the limitations of these three principles. The acknowledgment of these limitations gave rise to the European casuistry of the late Renaissance and Baroque era, which changed the very "mechanics" of interactions between a "general rule" and a "specific case".

\section{Casuistry}

Of course, casuistry as a science striving to resolve specific moral problems (or, as they are usually described in Catholic theology, special cases of conscience - casus conscientiae) arose in Europe long before the Renaissance. In the first centuries of the history of Christianity, clerics understood that faith and love alone could not form a solid foundation for morality; since the $4^{\text {th }}$ century, the treatise "De oficiis ministrorum" by Ambrose, Archbishop of Milan, has served as a model for Christian morality - in this work, virtues, whose sum formed a summum bonum of Christian ethics, were described according to the Ciceronian scheme; since the $8^{\text {th }}$ century, so-called "penitentials" (libri poenitentiales) containing lists of sins and their respective penalties, have been circulated; and by the $12^{\text {th }}$ century, when the clergy had to acknowledge that penitentials were not enough to deal with the endless variety of concrete cases and situations, casuistry had been born. However, up to the $16^{\text {th }}$ century, casuistry was shaped by the deduction of various private rules from the general principles of morality, and so resembled hermeneutics in the aforementioned sense of this word. Moreover, unlike the Judaic discipline, Christian ethical hermeneutics developed not so much by the multiplication of the rules of interpretation, as by an increase in the number of precedents. This led to the creation of ever more cumbersome moral codes containing innumerable clauses, additions, assumptions, and clarifications. By the $16^{\text {th }}$ century, the need for a new method to resolve moral problems had become obvious.

The development of such a method began after the Council of Trent (1545-1563), which aimed to strengthen the theological base of the Roman Catholic Church as it faced 
the imminent assault of Protestantism. And here the Society of Jesus played the leading role: as a result of the Jesuits' efforts, the methodology of so-called probabilism was worked out [5].

Probabilism was based on the conviction that the majority of moral principles can be subjected to rational discussion. The Jesuits rightly observed that if a person in his or her actions had to rely only on unquestioned and universal principles, he or she wouldn't do anything at all. In the sphere of morality, we are dealing not with general and indispensable truths, but with more or less plausible opinions (opinion probabilis), i.e. with opinions which are either shared by the majority of people or substantiated by some sort of authority. In each specific situation, a person has to choose between these opinions. Theoretically, the ethics of probabilism proceeded from the Aristotelian logic of believable opinions. According to Aristotle, plausible opinions are those, which "are accepted by everyone or by the majority or by the philosophers - i.e. by all, or by the majority, not by the most notable and illustrious of them" [6, I. 1.100 b 20]. To decide which of the plausible opinions should be chosen is possible only after the discussion and estimation of each opinion according to its consequences.

Of course, the Jesuits did not deny the existence of certain common a priori notions of good and evil: for example, the ten commandments of the Old Testament or the lessons of the Sermon on the Mount. These a priori notions form the contents of natural law, and a person should not have any doubts about them. But natural law is abstract and speculative (speculatio). To be implemented in real life (in praxi), natural law should be expressed as a positive law, some commonly accepted system of norms. Unlike natural law, this positive law can be subject to doubt and debate.

According to their casuistic classification, opinions can be, firstly, more reliable (probabilior) or less reliable (minus probabilis); secondly, more solid (tutior) or less solid (minus tuta). In accordance with this classification, casuistry has been divided into four branches: tutiorism, probabiliorism, equiprobabilism, and probabilism. Tutiorism assumed that we should follow only the most solid opinions, even if the less solid opinions are more plausible. According to probabiliorism, we may also follow non-solid opinions if they are more reliable than the opposite ones. According to equiprobabilism, we can follow a less solid opinion even if it and a more solid opinion are equally probable. Finally, according to probabilism, in certain situations, we can proceed from the least reliable and solid opinions. A paragon of probabilism, Herman Bousenbaum, wrote: "We would not commit any sin, following less probable... and solid opinion and rejecting the most probable and solid one, if we, firstly, do not endanger and harm our neighbours, and, secondly, if an accepted opinion is still probable" [7, Lib. I, Tr. I. C. II. Dub. II. Resp.]. In other words, in probabilism the opinion about the morality of an action is acceptable if it is to any degree probable and solid.

Many people reproached the Jesuits since in such a manner they could justify absolutely everything. It was likely to be so: the Jesuits often used probabilism to justify actions motivated not so much by moral or religious considerations as political ones. But probabilism is not the only way to prescribe ethical significance to amoral actions: we can reproach moral absolutism for allowing the same thing. In fact, probabilism is, firstly, the art of assessing the situation correctly, and secondly, the belief that a person is individually responsible for any choice. To clarify this, here is an old Jesuit example: Can a doctor operate on a patient if the probability of opinion that this operation will help is small, and the probability of opinion that the patient will die is great? The answer is: If the patient will 
certainly die without this operation, the doctor has moral grounds to take the risk of assuming full responsibility for the consequences of his actions [8, Examen III. Caput VI. 25].

This approach seems much more reasonable than the one that calls for the implementation of a "general duty" regardless of any circumstances. In my opinion, it can lay the foundations for the ethical expertise of any kind of activity: from medicine to culture.

\section{Between Absolutism and Relativism}

On the brink of the Enlightenment, probabilism was opposed by the ethical doctrines of Protestantism and Jansenism (which to a large degree resembled each other), and it was the Jansenists who particularly bitterly criticized the Jesuits' ethics. This criticism was expounded in the collective Jansenist treatises, written in the famous circle at the monastery of Port-Royal-des-Champs: "Théologie morale des Jésuites" (1644), "Factum pour les curés de Paris" (1658), and Blaise Pascal's "Lettres à un provincial" (1656). However, these writings analyzed and scoffed at some specific and substantial points of the Jesuit ethics. The logical foundations of anti-probabilism were summarized in the famous book by Antoine Arnauld and Pierre Nicole, "Logic; or, The Art of Thinking", which is commonly known as the "Port-Royal Logic".

It should be noted that the authors of the "Port-Royal Logic" regarded ethics as the main sphere for the application of logic [9]. The Aristotelian logic of plausible opinions (which lays the foundations for probabilism) became their primary target. This logic, Arnauld and Nicole argued, leads either to authoritarianism, that is, to the habit of relying on other people's opinions, or to skepticism, i.e. to the conviction that there is absolutely nothing reliable in the sphere of ethics. Instead of the principle of "plausible opinions", the authors of the Port-Royal suggested using the Cartesian principle of "evidence" or "intellectual intuition". According to this principle, one should "comprise nothing more in my judgment than what was presented to my mind so clearly and distinctly as to exclude all ground of doubt" [10, p.23]. The belief that moral judgments should be based on intuitively obvious and universal ideas has become a common methodological basis for the ethics of the Enlightenment: the Kantian a priori categorical imperative gave the perfect wording to this belief.

$20^{\text {th }}$-century philosophy claimed almost unambiguously that the enlighteners' project of the rational substantiation of morality has failed. But Positivist ethics (rising in response to ethical universalism and declaring ethical judgments to be simply emotional expressions devoid of meaning) relativized morality and completely eliminated any possible application of reason in this sphere. Moreover, Alasdair MacIntyre in his famous book "After Virtue" (1981) demonstrated that in the $20^{\text {th }}$ century such an emotivist approach to morality was inherent not only in Positivism but also in Weber's Rationalism, Existentialism, Analytical philosophy and other currents of thought alternative to Positivism [11]. If there are no efficient methods allowing for the justification of moral norms and assessments, then we cannot get rid of Emotivism. Thus, modern ethics must find some "middle ground" between the Universalism of the Enlightenment and the Relativism of the Modernity ${ }^{1}$. Giving that, it is not surprising that a kind of revival of casuistic method-

${ }^{1}$ It is worth noting that today both moral dogmatism and relativism are unacceptable. The authors of a paper on legal ethics note: "In modern society to defend the existence of some absolute morality and eternal moral values mean to stand on very questionable ground. At the same time, the comprehensive exposition of 
ology has happened at the end of the last century, primarily in the sphere of applied ethics and ethical expertise.

The most vivid example of such a revival can be found in the book written by Albert R.Johnson, a specialist in bioethics, and Stephen Tulmin, an expert in scientific methodology: "The Abuse of Casuistry: A History of Moral Reasoning" (1988) [13]. It is important to emphasize that both authors have worked for some time in the National Commission for the Protection of Human Rights. Johnson and Tulmin were surprised that while addressing specific problems and circumstances, members of the Commission, who had different religious and scientific views, could easily find a compromise: they moved from some standard examples of "right" and "wrong" to more and more marginal cases. But as soon as they began to use their favored religious beliefs, moral principles, or ethical theories in argumentation, compromise became unattainable. These observations prompted the authors to investigate the history of moral reasoning. In the book they give a detailed overview of the history of casuistry, and bring the reader to the conclusion that our everyday practical moral decisions are unconsciously taken in accordance with casuistic methods, even though these methods were compromised during the Enlightenment: while making a moral judgment, we rely not only on emotions, but also remember known opinions, and assess the consequences of our actions. The authors draw the following conclusion: to resolve moral controversies, we should move not only "downwards" (i.e. from moral theories to specific cases), but also "upwards" (i.e. from concrete cases to moral theories). To assess the morality or immorality of a particular situation, not only ethical principles and doctrines but the situation itself can be used to assess the relevance or irrelevance of certain ethical principles and doctrines.

In my opinion, Johnson and Tulmin's conclusions are correct but need some methodological clarification. Of course, all moral principles, religious commandments, and ethical theories should be considered in practice as plausible opinions (opinio probabilis), which cannot be a priori applicable to any situation. But the possibility to use them should depend on so-called satisfiability. In deontic logic, "satisfiability" and "unsatisfiability" have long been used as an analog of truth and falsehood for imperative (normative) sentences. Usually, satisfiability means physical feasibility of a prescribed action. It seems to me that in the sphere of ethics, satisfiability should be expanded and obtain the meaning of solidity (tuta) in the traditional casuistic sense. A requirement is satisfiable if it does not contain any threat to human life, freedom, or dignity, and does not obviously contradict other moral requirements. The most important consequence of this approach to ethics will be the replacement of the traditional abstraction of universality (general validity) and necessity of moral requirements by the abstraction of their potential satisfiability ${ }^{2}$. The moral code includes norms that can potentially be satisfied, but, at the same time, cannot be a priori applicable to all possible cases. If the abstraction of the universality and necessity of moral norms corresponds to the principles of ethical dogmatism (the calling to fulfill one's duty regardless of circumstances), and to deny it means to accept relativism (permitting the existence of mutually exclusive moral codes), then the abstraction of potential satisfiability corresponds to the ideal of "Situational ethics" that presupposes "flexibility" of moral norms dependant on circumstances.

the world-view denying the existence of morality in general and its relevance in particular also raises some questions - if not theoretical than in the sphere of applied and professional ethics" [12, p. 38].

${ }^{2}$ Further on the abstraction of potential satisfiability, see: [14]. 
How can we use this in the ethical expertise of cultural phenomena? Of course, neither the identification of moral doctrines with probable opinions nor the replacement of the abstraction of universality and necessity of moral requirements with the abstraction of their potential satisfiability is enough to make such expertise relevant or "objective". We can term "justified" only those conclusions which are satisfactory to all the experts. But there can be no consensus, for example, among those for whom their religious feelings are of supreme value, and those who put freedom of conscience above all else. Therefore, any ethical expertise should be based not on the beliefs and principles of experts, but on an assessment of a specific situation and a comparative analysis of the possible consequences occasioned by the application of some moral requirements in this specific situation.

\section{Conclusion}

Thus, casuistry as a method of ethical expertise implies not only an examination if a specific case corresponds to general moral principles, but also an examination if these general moral principles are applicable to some particular cases. Such expertise provides not only a moral assessment of events but also an assessment of morality itself (and, contrary to the prevailing opinion, morality is not something unchangeable and conservative). Moralities are changeable and can be developed, while ethical expertise (and, specifically, expertise of cultural phenomena, which by their very nature are provocative and unstereotypical) may become an important factor in the development of public morals.

\section{References}

1. Popper K. R. The open society and its enemies, vol. 2 "The spell of Plato". London, George Routledge \& sons, $1945.268 \mathrm{p}$.

2. Aristotle Ethica Nicomachea, trans. by W. D. Ross. The works of Aristotle, trans. into English under the editorship of W. D. Ross, vol. IX. Oxford, Clarendon Press, 1925, pp. 350-481.

3. Gadamer H. G. Truth and method, transl.by J. Weinsheimer and D. G. Marshall. London, New York, Continuum, 2004. 601 p.

4. Kacenel'son L. I. Middot ili metody tolkovaniia [Middot or methods of interpretation]. Available at: https:// ru.wikisource.org/wiki/ЕЭБЕ/Миддот_или_методы_толкования (accessed: 20.03.2018). (In Russian)

5. Brodsky A. Casus conscientiae. Kazuistika i probabilizm s tochki zreniia sovremennoi etiki [Casus conscientiae. Casuistry and probabilism in terms of modern ethics]. Homo philosophans, Solonin J. N., ed. St. Petersburg, St. Petersburg State University, 2002, pp. 279-294. (In Russian)

6. Aristotle. Topica and De sophisticis elenchis, trans. by W. A. Pickard-Cambridge. The works of Aristotle, trans. English under the editorship of W. D. Ross, vol. I. Oxford, Clarendon Press, 1928, pp. 20-546.

7. Busenbaum H. Medulla theologiae moralis. [Coloniae, Freie Reichsstadt, 1694]. 556 p.

8. Escobar y Mendoza A. Liber theologiae moralis [Parissis, France, 1656]. 854 p.

9. Arnauld A., Nicole P. La Logique, ou lart de penser, éd. critique par Dominique Descotes. Paris, Champion, 2011. 427 p. (In French)

10. Descartes R. Discours de la méthode, ed. A. Robinet. Paris, Larousse, 1969, 140 p. (In French)

11. MacIntyre A. After Virtue: A Study in Moral Theory. South Bend, University of Notre Dame Press, 1981. $252 \mathrm{p}$.

12. Derzhivitskij E. V., Larionov I. Yu., Perov V. Yu. K voprosu ob etike prava [Revisiting the ethics of law]. Vestnik of Saint Petersburg University, ser. 17, Philosophy. Conflict studies. Culture studies. Religious studies, 2016, is. 4, pp. 33-45. (In Russian)

13. Jonsen A.R., Toulmin St. The Abuse of Casuistry: A History of Moral Reasoning. Berkeley, University of California Press, 1988. 420 p. 
14. Brodsky A. On the possibility of constructivist substantiation of ethics. International Multidisciplinary Scientific Conference on Social Sciences and Arts, SGEM 2017, 28-31 March 2017, book 2, vol. 1. Vienna, 2017, pp. 307-314.

Received: 13.02.2018 Accepted: 10.05.2018

Author's information:

Alexander I. Brodsky -Dr. Sci. in Philosophy, Professor; abrodsky59@mail.ru

\title{
Правдоподобные мнения и безопасные следствия: к вопросу о методологии этической экспертизы в сфере культуры
}

\author{
А. И.Бродский \\ Санкт-Петербургский государственный университет, \\ Российская Федерация, 199034, Санкт-Петербург, Университетская наб., 7-9
}

Для цитирования: Brodsky A. I. Probable opinions and solid outcomes: On the methodology of ethical expertise in the cultural sphere // Вестник Санкт-Петербургского университета. Философия и конфликтология. 2018. Т. 34. Вып. 3. С. 324-332. https://doi.org/10.21638/11701/spbu17.2018.301

Применение зародившейся в сфере биомедицинских исследований этической экспертизы к области культуры выявило главную проблему любой экспертизы подобного рода: отсутствие методологии, позволяющей хотя бы частично устранить влияние таких «субъективных факторов», как идеологические и религиозные предпочтения экспертов, их личные моральные качества, эмоциональные реакции. Попытка найти такую методологию - основная цель данной статьи. Для решения этой задачи автор предлагает обратиться к забытому искусству казуистики, наивысший расцвет которой приходится на конец XVI - начало XVII в. Главная черта казуистики того времени - рассмотрение различных этических принципов и норм в качестве лишь более или менее правдоподобных мнений (opinion probabilis). Решить, какое из этих мнений следует выбрать, можно лишь путем их обсуждения и оценки каждого мнения по следствиям, вытекающим из него в каждом конкретном случае. Применение казуистики к современной этической экспертизе предполагает, что эксперты должны исходить не из своих убеждений и принципов, а из оценки конкретной ситуации и сравнительного анализа возможных последствий применения к ней тех или иных моральных требований. Обоснованным может считаться такой вывод экспертизы, по поводу которого ее участникам удалось заключить консенсус. Но такой консенсус будет невозможен, если участники экспертизы будут обосновывать свои выводы не анализом последствий тех или иных решений, а своими любимыми религиозными или идеологическими доктринами. В теоретическом плане автор статьи считает, что казуистика как метод этической экспертизы предполагает не только оценку частного случая с точки зрения его соответствия общим принципам нравственности, но и оценку самих принципов нравственности с точки зрения их применимости к частным случаям.

Ключевые слова: этика, экспертиза, культура, казуистика, мнения.

Контактная информация :

Бродский Александр Иосифович — д-р филос. наук, проф.; abrodsky59@mail.ru 